\title{
Structural and Functional Bases of Formational, Institutional and Procedural Mechanism Using Power Resources of Stalin's Totalitarian Regime in Western Ukraine at the Final Stage of the Second World War
}

\begin{abstract}
The presented scientific, theoretical and practical aspects of the topic are considered an important prerequisite for understanding the causes and results of the mass use of the deportation repressive tool in the intensive consolidation of Stalin's totalitarian regime in "class hostile environment" and the consequences of such a policy for the western region development, particularly at modern stage, including the Ukrainian political nation-building and the independent Ukrainian state, which is now experiencing challenges and threats that are rooted in the totalitarian past.

Stalinism, as a particular political regime, was established in the western regions of Ukraine at the final stages of World War II and can be defined as a kind of left extremist totalitarianism.

The main components of the efficiency of the Stalinist totalitarian regime based on the mass use of political violence and terror through the branched structure of repressive secret police. Functions of the NKVS, NKVD, prosecutors, and courts followed the strategic objectives of Stalin's totalitarian regime in a hostile social and national environment in Western Ukraine in the complex military and political conditions of the final phase of World War II. Effective and timely implementation of policy priorities of Stalinism in the region allowed to create an appropriate institutional and procedural system, which was based on the large-scale use of political violence and employed such characteristic tools as terror, repression, deportation.
\end{abstract}

Keywords: Western Ukraine, World War II, Stalin's regime, repressive and punitive organs, political violence

The presented scientific, theoretical and practical aspects of the topic are considered an important prerequisite for understanding the causes and results of the mass use of the deportation repressive tool in the intensive consolidation of Stalin's totalitarian regime in "class hostile environment" and the consequences of such a policy for the western region development, particularly at modern stage, includ- 
ing the Ukrainian political nation-building and the independent Ukrainian state, which is now experiencing challenges and threats that are rooted in the totalitarian past.

The first researcher to investigate place, issues and the role of repressive secret police as a support of Stalin's totalitarian regime in Ukraine was Ivan Bilas ${ }^{1}$. Modern Ukrainian political scientists and historians S. Vonsovych ${ }^{2}$ and I. Terletska ${ }^{3}$ analyze theoretical and methodological basis of the nature of totalitarianism, including the specifics of its manifestations in Ukraine. Complex historical and political analysis of the nature, strengthening mechanisms and consequences of the establishment of the Stalin's totalitarian regime in Western Ukraine was made by B. Yarosh ${ }^{4}$. It is worth to mention monographs of T. Vronsky ${ }^{5}$ and J. Nadolskoho ${ }^{6}$ as the latest developments of Ukrainian historiography in the outlined issues.

Power resources are the essential element in the exercise of power. They are a set of tools through which power is effected in accordance with the objectives of the subject.

Based on the general classification of political regimes to democratic and non-democratic, authoritarianism can be attributed to the latter category (as a form of government in which the power of the ruler or ruling group is not restricted by law and not under the control of individuals who are removed from the decision-making process) and so can totalitarianism (political regime and social system characterized by violent political, economic and ideological dominance of the ruling elite, organized into a coherent bureaucratic party-state apparatus headed by the leader, total control over society and the individual, and unfettered intrusion into all spheres of citizen's life).

A more detailed analysis of totalitarianism as a political regime reveals the following features: firstly, rejection of liberal-democratic institutions, human rights and freedoms; secondly, omnipotence and monopoly of information of hierarchi-

1 І.Г. Білас, Репресивно-каральна система в Украӥні 1917-1953: суспільно-політичний та історико-правовий аналіз, Книга 1, 2, Київ 1994.

2 С.Г. Вонсович, Аискурс тоталітаризму (політологічний аспект), Київ 2008.

3 І.В. Терлецька, Сучасний історіографічний дискурс сталінізму як форми тоталітаризму, Київ 2009.

4 Б.О. Ярош, Сторінки політичної історії західноукрайнських земель (30-50-ті рр. XX cm.), Ауцьк 1999; idem, Тоталітарнийрежим на західноукраїнських землях 30-50-ті роки XX століття (історико-політологічний аспект), Ауцьк 1995.

5 Т.В. Вронська, Позасудові репресії иленів сімей учасників національно-визвольного руху в західних областях України (1944-1952), Київ 2008.

6 Й.Е. Надольський, Аепортаційна політика сталінського тоталітарного режиму в західних областях України (1939-1953 рр.), Ауцьк 2008. 
cal corporate organizations; thirdly, public and/or private ownership of means of production under strong bureaucratic control; fourthly, administrative regulation of economy, centralized distribution, significant role of forced labor and non-economic coercion, providing free of charge or cheap labor; fifthly, ensuring order realization as a rigid system of rules and principles that give absolute priority to rights and interests of a particular class, nation, race or exclusive group; sixthly, substitution of political loyalty (moral choices, respect for the laws and interests of people) with mafia-type rigid loyalty; seventhly, statutory regulation of the all aspects and functions in the society, characterised by paternalism and human alienation from the political process; eighthly, messianic state ideology with pretensions to world domination; ninthly, militaristic, economic and cultural expansionism in foreign policy, coupled with country isolation; tenthly, militarization of the economy and society; eleventhly, a national - class charismatic leader as a fundamental element of political and legal ideology ${ }^{7}$.

In genaral, Stalinism, as a social system, shares the features inherent in the classical model of totalitarianism, however, Stalin's totalitarianism and its implementation in Ukraine have their own specific characteristics. Ukrainian researchers include among them great-power chauvinism, Ukrainian genocide, brutal collectivization, which manifested itself mainly in artificial famines, and anti-Ukrainian orientation of repression.

As I. Terletska rightly observes, the term "Stalinism" is rather ambiguous. Firstly, Stalinism today is understood as a certain type of a totalitarian social system. Secondly, some scholars understand Stalinism as an official ideology created and planted by Joseph Stalin on the basis of his own interpretation of Marxism and Leninism. Thirdly, Stalinism is understood broadly: as a type of political regime, a form of political system, a kind of ideology that prevailed at the time of Stalin's personality cult, a certain type of civilization that includes all aspects of life (political, economic, spiritual and cultural, social, private, etc.), and as a certain type of social mentality (where the dominant feature is fear) ${ }^{8}$.

B. Yarosh correctly pointed out that the totalitarian Soviet system was introduced in Western Ukraine in the period of its greatest prosperity. The government moved to massive repression when faced with contestation and opposition to many of its actions. Among the most tragic cases were mass repressions and deportations ${ }^{9}$.

7 С.Г. Вонсович, ор. cit., pp. $72-73$.

8 I.В. Терлецька, ор. cit., pp. 29-30.

9 Б. О. Ярош, Тоталітарний режим на західноукрайнських землях в 30-50-х роках XX столітmя (історико-політологічний аспект): автореф Аис... А-ра політ. наук: спец.: 23.00.02, 
Political analyst Vladimir Tomahivym proposed a periodization of Stalinism establishment in Western Ukraine, which includes three main phases: 1939-1941 - the initial period, during which formed ("exported") were key national, political, social and economic institutions; 1944-1952 - a transitional period characterized by operation at full capacity of all the organs that formed the totalitarian power and simultaneous elimination of the real political and ideological alternative in the form of the OUN, UPA, and the Ukrainian Greek Catholic Church; 1950 's - the final consolidation period of Stalin's totalitarian regime ${ }^{10}$.

According to T. Vronsky, the Soviet government had at its disposal two different, but equally effective, mechanisms of repression: tyranny and law. Society did not know the latter at all, because only those who represented the law had the right to refer to it ${ }^{11}$.

B. Gulay points out that speedy elimination of regional features in the socio-political and spiritual spheres as well as economic, ethnic, and social structure of public administration was accompanied by political repression ${ }^{12}$. In our opinion, it was to provide the desired result, which is testified to be the effective functioning of Stalin's totalitarian regime in the western region in the complex military-political circumstances.

Repressive and punitive organs were an important tool for strengthening the totalitarian regime in the western region, where the main task was to deal with the struggle of the Ukrainian national liberation movement and the Polish armed underground.

Activities of the Soviet regime were aimed at the destruction of the existing structures of the Army and the Government Delegature of Poland. Operation "Seimas" was launched for this purpose under orders from Moscow. The idea of this operation arose in 1943. The party-state leadership and the leadership of the KGB of the USSR and the URSR had information about emissaries of the Polish exile government in the United Kingdom to the territory of Western Ukraine to control the Polish underground and to carry out sabotage activities ${ }^{13}$. F. Tsvyetuhina

Інститут національних відносин і політології НАН України 1995.

10 В. Я. Томахів, Сталінізм якрізновид тоталітаризму: автореф. Аис... канА.. політ. наук:

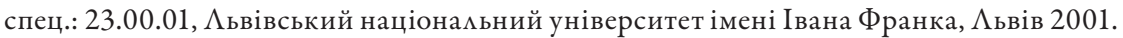

11 Т.В. Вронська, ор. cit.

12 В. В. Гулай, Етносоціальні прочеси в західних областях України (друга половина 40-х 50-mi роки $X X$ cm..): автореф. Аис... канд.. іст. наук: спец.: 07.00.01, Аьвівський національний університет імені Івана Франка, $\Lambda$ ьвів, 2002.

13 Польща та Україна у тридиятих - сороковихроках ХХ століття. Невідомі документи з архівів спещіальних служб, Vol. 6: Операція «СЕЙМ» 1944-1946, еd. Є. БеАнарек, Ю. Шаповац, Варшава-Київ 2007, р. XXIV. 
stated in the chief UNKDB certificate of Rivne region on 7 of June 1944 that many of those arrested members of the Polish armed underground expressly committed no action against communist structures and waited for appropriate guidance. However, as the Red Army moved to the west, the activity of Soviet secret police agencies increased ${ }^{14}$.

47 active members of $\mathrm{AK}$ were arrested almost immediately after joining the Red Army in Ukraine, including 29 interned officers ${ }^{15}$. The case of agent's "Sejm" for the development of 300 active members of the Polish military and political underground was created on 31 July 1944 in UNKDB in the Lviv region ${ }^{16}$. The arrest of the leadership of the Polish underground in late summer of 1944 virtually eliminated the Polish factor of organized resistance to the Soviet political system in the region.

OUN and its militias were continuing to struggle against it. 2207 UPA military action were held only in the first half of 1945 trying to prevent the establishment of the Soviet government and management ${ }^{17}$. However, the advantage was on the side of the Stalin's regime, which used the most brutal measures to overcome opposition to its policies.

The method that had corrosive effect on the public opinion of inhabitants of the region were public executions of UPA members and defiling their corpses ${ }^{18}$. Even the resolution of the CC CP (b) U in March 1945 caused numerous instances of violence against the local Ukrainian population of the Rivne, Stanislav, and Ternopil regions, which was justified as a struggle of Ukrainian-German nationalists, such as in response to the firing of a group of Soviet workers near the village Krasyyeve Koropetsky district, NKVD operative group in the Ternopil region committed a massacre of the inhabitants of this village, burned more than 100 homes, shot 6 people, including the father of a soldier of the Red Army M. Gron ${ }^{19}$. The victims were opposition and representatives of other ethnic groups. So, with the support of the UPA, soviet government bodies burned 16 of Czech households in the village Sofievka in the Rivne region ${ }^{20}$.

${ }^{14}$ Ibidem, p. XXX.

${ }_{15}$ Центральний державний архів громадських об’єднань України, Ф. 1, Оп. 23, Спр. 926, Арк. 85.

16 Польща та Україна у..., р. 642.

17 І.Г. Білас, ор. сіt., Книга 1, p. 272.

18 Ю. Киричук, Нариси з історії українського начіонально-визвольного руху 40-50-х років

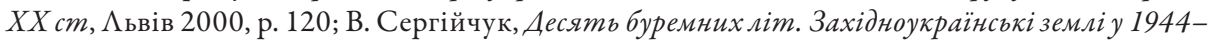
-1953 рр.: Нові документи іматеріали, Аніпро 1998, pp. 194-195.

19 В.О. Котигоренко, Етнічні протиріччя і конфлікти в сучасній Україні: політологічний концепт, Світогмяа 2004, pp. 122-123.

20 Ibidem, p. 145. 
Local residents became the victims of the repressive and punitive actions, committed by the Soviet power structures from the first days of the western Ukrainian region occupation. On 19 August 1944 the NKVD's (People's Commissariat for Internal Affairs) subdivision burned the village of Pyriatyn in Zhovkva district, having shot 50 residents, and on 28 August punitive detachment surrounded the village of Synkovychi near Rava-Ruska, burned it and shot the whole male population. A day later NKVD massacred the inhabitants of the village of Hrabivets' in Bogorodchany district in the Stanislav region, which resulted in murder of 80 residents and burning the village ${ }^{21}$.

In order to strengthen the fight against the UPA (the Ukrainian Insurgent Army) in 1944 internal troops of the NKVD were sent to Western Ukraine. According to the information of 9 October 1944, troops were redeployed in Western Ukraine from Moscow, Baku and Transbaikal. Within these troops there were even armored trains ${ }^{22}$. In 1944 the deployment of troops in the region was as follows: the Volyn' region - one division of the NKVD troops, three regiments and one brigade, the total number of 5285 persons; the Rivne region - one division and four brigades, the total number of 8754 persons; the Lviv region - four brigades and one cavalry regiment counting 6525 persons; the Ternopil' region - three brigades counting 3057 soldiers; the Stanislav region - brigade counting 1,328 people $^{23}$. In addition, there the Red Army units were used more often and this refutes the allegation of the Soviet propaganda that the struggle at that time was against uncoordinated "bandit groups of Ukrainian-German nationalists". Only in April 1944 departments of Soviet military counterintelligence SMERSH together with army units conducted 440 operations against units of the UPA and OUN members in 270 settlements in the Rivne, Stanislav, Volyn' and Ternopil' regions. This resulted in detention of more than 9 million people, including 534 active members of the OUN (the Organization of Ukrainian Nationalists) and UPA and murder of 260 people ${ }^{24}$.

Population of the western regions suffered significant losses due to Stalin's repressive policy towards members of the Ukrainian national liberation movement. The Chief of fight against gangsterism of the soviet NKVD Lieutenant General

21 Ю. Киричук, Нариси з історії українського нащіонально-визвольного руху 40-50-х років

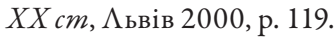

22 І.Г. Білас, ор. сit., Книга 2, р. 482.

23 Б.О. Ярош, Тоталітарний режим на західноукрайнських землях 30-50-ті роки XX столітmя (історико-політологічний аспект), Ауцьк 1995, р. 88.

${ }^{24}$ Центральний державний архів громадських об’ єднань України, Ф. 1, Оп. 23, Спр. 928, Арк. 35. 
Leontiev pointed out in a memorandum dated 3 August 1945 that in the western regions of Ukraine 34210 insurgents were, 46059 were captured, and 3797 were arrested for the assistance of the OUN and UPA ${ }^{25}$.

From February to December 1944 from the region deported were 4,744 families (13,320 people) of so-called gangs accomplices, including 3582 persons from the Volyn' region, Lviv - 3165 persons, Rivne -3212 persons $^{26}$. In January 1945, 485 families were deported from the Drohobych region ${ }^{27}$.

On 15 May 1945 in Lviv Khrushchev held meeting of the regional committee secretaries of the Communist Party (Bolsheviks) and the heads of NKVD departments. He insisted to conduct repression towards the population more resolutely, to evict families of rebels to remote areas of the USSR, and to organize meetings of the peasants, on which to announce the names of those who help the rebels and apply terror against them ${ }^{28}$. Local leaders immediately begun to carry out these resolutions. By 1 June 1945, 9615 families were evicted from the western regions of the USSR of nearly 24.9 thousand persons of so-called gangsters and their accomplices $^{29}$.

Leaders of the USSR and the Ukrainian SSR explained mass deportations of 1944 - early 1945 by the fact that a country at war must fight actively not only with external, but also with internal enemies - "accomplices" of the former. Among other things, the deportation from Western Ukraine was seen as punishment for opposing the Soviet authorities and the fight against the Red Army. This is an irrefutable fact that the Stalin's regime failed to articulate, for tens of thousands of women, children and the elderly persons were punished so severely. The evidence of this was the absence of any state law or decisions on that matter. The high-ranking persons, as always, limited themselves to individual departmental solutions of NKVD adopted in March-April 1944. They, as well as the following repressive practices of punitive bodies, laid new traditions as well as forms and methods of deportation, which continued in the following years ${ }^{30}$.

As J. Nadolskyy summarized, deportation policy in the western regions of Ukraine was developed and implemented under the leadership of the Political Bureau (Politburo) of the CPSU (b) (Communist Party of the Soviet Union), and also

\footnotetext{
25 І.Г. Бікас, ор. cit., Книга 1, р. 272.

26 Ibidem, p. 270.

27 АА $А$, ФонА П-5001, Арогобицький обласний комітет Комуністичної партії України, Опис 6, Спр. 57, Арк. 106

28 І.Г. Бікас, ор. cit., Книга 1, р. 271.

29 ЦААГО України, Ф. 1, Оп. 75, Спр. 4, Арк. 23.

30 Т.В. Вронська, ор. cit., p. 90.
} 
was directed from the Kremlin relevant directives, circulars and regulations. All significant issues of repressive actions were governed documentarily: the timing and stages of operations, their scope, target groups and regional limits, extent of punishment, machinery relocation, and appointment of executive personnel. Key decisions on deportation policy adopted by the Politburo of the CPSU (b) were concretized in the documents of Sovnarkom (Council of People's Commissars) or Executive Committee. Resolutions of all senior public institutions relevant to the decisions of the Politburo were taken on the same or on the next day. Following the approval, relevant documents were passed along the whole vertical structure: they were duplicated on the level of the Central Committee of the Republic, the Central Executive Committee and Council of Commissars of Ukraine, and then at the regional level. Normative documents and instructions on the maintenance of order and resettlement of deportees in resettlement areas were developed and distributed through a system of NKVD departments. Relevant political and ideological work was carried out in the mass media, using other channels of influence on the local population ${ }^{31}$.

One should also mention A. Trukhan's point of view, who says that Soviet authorities carried out a policy of eliminating the national liberation movement in Western Ukraine with the help of a "carrot" and a "stick" (amnesty of the UPA members, who came to confess, revealing struggle with the "distortion of the party line" in the collective farms, etc.). In these circumstances, the public prosecutor was assigned the role of a "good cop" who, in contrast to the "evil cop" (NKVD, Ministry of Internal Affairs) had to correct their errors, miscalculations and outright lawlessness. In general, all the structures of the Soviet punitive and repressive machine worked for one final result; the question was only how to share the responsibilities ${ }^{32}$.

M. Polikovskyy rightly points out that the characteristics of the police work was conditioned by the general socio-political and socio-economic reasons. First of all, the police intended to eradicate clandestine (underground) activity of the OUN-UPA. And only when in the early 1947 the function of the struggle against domestic underground activity was assigned to the organs of state security, the main police forces were directed towards fighting crime ${ }^{33}$.

31 Й.Е. НаАОАьський, ор. cit.

32 А.Я. Трухан, Прокуратура західних областей Украӥни у 1944-1953 pр. (історико-правовий aсnекm): автореф. Аис... канд. юриА. наук.: спец.: 12.00.01, Національний Університет «

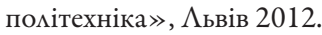

33 М.Ф. Поліковський, Мілічія західних областей України в 1945-1950 pp. (політико-nравовий аналіз діяльності: автореф. Аис... канА.. юриА. наук: спец.: 12.00.01, Університет внутрішніх справ, 1995. 
Police forces were recruited mainly from the personnel that arrived from the eastern regions of the country. By 1 January 1945, Russians constituted 45.3\% of NKVD workers in the Drohobych region, $57.4 \%$ among guiding employees. Russians accounted for $71 \%$ employees of state security bodies in the region. In particular, in the Drohobych region out of 26 heads of city and district departments of NKVD management 16 were Russians. In general, among all workers of the repressive and punitive bodies in the Drohobych district Russians constituted $47.9 \%$, and Ukrainians $-47.6 \%$. The majority of Ukrainians were also sent from other regions of the USSR, demobilized from the Red Army or partisan groups. Thus, in the the Volyn' region to the position of judge in 194531 persons were appointed from the newly arrived and there were only two local nominees. No local residents were appointed to the prosecutor's office ${ }^{34}$.

The internal affairs bodies were given broad rights and they operated outside the control of other governmental bodies and the society. In particular, overseeing of the public prosecutor's office over the legality of police actions was reduced to the formal aspects. In the newly joined western regions of Ukraine there were two or even three legal systems with two (or three) bodies, which de facto played the role reserved in law for the prosecution: a) actual prosecutors - for unaffiliated persons and members of the party, whose bringing to justice it received the sanction of the communist party body; b) district party committee for ordinary party members who could lead them out of the law by refusal to give sanction for criminal prosecution; c) bureau of the regional committee, the communist party of the Union republic or the central committee of the communist party, if the offender was a so-called nomenclature ${ }^{35}$.

Extreme conditions of war led the Soviet leaders for wide usage of irregular military units and parts - voluntary forces of self defense of militarized and non-military nature. The most massive among them became destroyer battalions and groups of public order prevention, which operated under the auspices of law enforcement and the general guidance of the party and state structures. The operation of these units in the western areas liberated from the Nazi occupants, except for performing their basic tasks determined by the order of the NKVD dated 25 June 1941, was directed at suppressing the national liberation movement by limiting the access of OUN-UPA militias to the settlements to gain members or supporters and food resources. Secondly, in 1944 and the first half of 1945, the most

34 В. Гулай, Кадрова політика радянського режиму в західних областях Украйни (друга помовина 40-x - 50-mі роки XX cm.), Серія історична, Вип. 37, Част. 2: Аокументи та матеріаци.

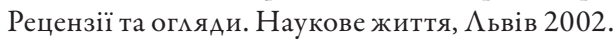

35 A.Я. Трухан, ор. cit. 
of destroyer battalions personnel were representatives of the Polish nationality, living densely in locality. Their mass entry into these formations was explained by the need to protect themselves from OUN-UPA detachments and desire to repay for the violence against the Polish population in the Volyn' and Carpathian region in the years 1943-1944. However, the presence of weapons made it possible for the Polish fighters to abuse their official position and resort to harassment of peaceful Ukrainian population. Since the second half of 1945, due to mass migration of the Polish people to Poland in accordance with the intergovernmental agreement of 9 September 1944 concluded in Lublin, the public formations personnel of self-defense were formed mainly from Ukrainians. So the Soviet authorities artificially created the conditions for the split of Ukrainian citizenship of the western regions of Ukraine and the fratricidal war. Some of the male population, who supported the national liberation movement or were its illegal participants, consciously or by order of their superiors joined the destroyer battalions and later helped to replenish arms and ammunition of the UPA armed forces, as it was evidenced by numerous cases of "treason" and disarmament of public self-defense formation $s^{36}$.

Therefore, totalitarianism as a political regime and social system is characterized by violent political, economic and ideological dominance of the ruling elite, organized in a coherent bureaucratic party-state apparatus, headed by the leader, with the total control over the society and the individual, and unfettered intrusion into all spheres of public life. The dominant role in the system of totalitarian government resources are played by power resources of authority, like weapons and apparatus of physical coercion, and specially trained people. The essential features of the political regime, which was created in the western regions of Ukraine in the final stages of World War II, can be defined as a kind of left extremist totalitarianism - Stalinism. The main components of the efficiency of the Stalinist totalitarian regime were based on the mass use of political violence and terror through an extensive structure of repressive punitive bodies. The activity of the NKVD, the Office of Public Prosecutor and the courts followed the strategic tasks of Stalin's totalitarian regime in a hostile social and national environment of the Western Ukraine in the complex militarypolitical conditions of the final stage of World War II.

Appropriate institutional and procedural system had to provide effective and operative implementation of the policy priorities of Stalinism in the region. This system was based on large-scale use of political violence in such its characteristic forms as terror, repressions and deportation.

36 В.О. Резницька, Організаційно-правові основи діяльності добровільних громадських формувань самооборони в 1944-1954 рр. (за матеріалами західних областей УРСР): автореф. Аис... канА. юриА. наук.: спец.: 12.00.01, Маріупольський Аержавний університет, Маріуполь 2012. 